\title{
The Emergence of Physical Education as a Subject for Com- pulsory Schooling in the First Half of the Nineteenth Cen- tury: The Case of Phokion Heinrich Clias and Adolf Spiess
}

\author{
Rebekka Horlacher
}

Abstract • In general, schooling and nation-building are associated with the unifying role of language and history education, since language and culture are perceived as fundamental pillars of the nation. Less discussed - at least regarding the curriculum — is the role of physical education, even if physical education was a highly political issue in the first decades of the nineteenth century. Based on a case study of Switzerland and textbooks for physical education by Adolf Spiess and the activities of Phokion Heinrich Clias for the Bernese school, this article discusses how physical education, distinct from the late seventeenth and eighteenth centuries' care for the body, became a school subject of the nineteenth century compulsory schools and how it was related to the notion of nation and nation-building. It argues that physical education became first part of the "modern" philanthropic education and schooling, was soon taken for granted as an essential curricular component of nation-building and lost thereby the political threat.

Keywords • schooling, curriculum, physical education, nation-building, philanthropic education

Normally, the history of physical education is traced back to the ideas and initiatives of Friedrich Ludwig Jahn (1778-1852), also known as "Turnvater Jahn" and to military requirements such as physical strength and military force. ${ }^{1}$ In doing so, a particular meaning of physical education is stressed: that of physical education as a school subject of the compulsory schools with a specific set of gymnastic exercises aiming at a healthy body (and soul) for the students making them valuable members of a political entity, that is, the nineteenth-century nation-state. Be it as it is, physical education was not just preparation for military service nor the exclusive 'invention' by Jahn, even though his role in popularising physical education —or Turnen —in the first half of the nineteenth century in Germany can hardly be overestimated. ${ }^{2}$ Yet, when Jahn began to advocate Turnen as a national public - not necessarily as a curricular - activity, physical education had already been part of the educational discourse, featured in guidebooks for child-rearing already in the seventeenth and eighteenth centuries. ${ }^{3}$ These guidebooks, often written by paediatricians, discussed

1 See for example Roland Naul, "History of Sport and Physical Education in Germany, 1800-1945," in Sport and Physical Education in Germany, ed. Ken Hardman and Roland Naul (London: Routledge 2002), 16.

2 See article by Daniel Tröhler in this special issue.

3 See for example Roger Mercier, L'enfant dans la société du XVIIIe siècle (Dakar: Université de Dakar, 1961); Sabine Toppe, Die Erziehung zur guten Mutter. Medizinisch-pädagogische Anleitung zur Mutterschaft im 18. Jahrhundert (Oldenburg: Oldenburg Universität, 1993).

Rebekka Horlacher is a lecturer at the Zürich University of Teacher Education and a Senior Researcher at the Institute of Education at the University of Zurich, Switzerland.

Email: rebekka.horlacher@phzh.ch

Nordic Journal of Educational History 2017. (c) Rebekka Horlacher. This is an Open Access article distributed under the terms of the Creative Commons CC-BY4.0 License (http://creativecommons.org/licenses/by/4.0/). 
physical education typically in the context of health and the overall condition of the body. ${ }^{4}$ Recommendations were made regarding appropriate clothing, the frequency and correct temperature of baths, suitable diet restrictions, and so on. Some guidebooks combined the education of the body with the education of the mind and soul, and also made recommendations regarding questions of appropriate conduct. A famous example of this kind of literature is John Locke's Some Thoughts Concerning Education (1693), which was translated into many languages and widely read across eighteenth century Europe and referred to by the so-called modern educators of the late eighteenth century. ${ }^{5}$

Around 1800, the key question of educational strategies, how to prepare people for conducting a "good life" in a given social order, got new attention. At the same time there was a shift in Europe in the context of the discourse of nation-building, with consequences for physical education. It was a widespread goal of the advocates of compulsory schooling to fabricate the future citizens through mass compulsory schooling, because the new "nation-states" that were established after the Congress of Vienna in 1815 faced the problem of how to transform the former inhabitants of territories into citizens of the new States.

While the role of teaching history and language became and still is the main topic in studies of schooling and nation-building, ${ }^{6}$ physical education is less discussed and, if it is, with emphasis on the second half of the nineteenth century and the 20th century. ${ }^{7}$ This is the case even though early nineteenth century promoters of physical education believed their aspirations were closely linked with national considerations. ${ }^{8}$ Against this background, the central question raised here is how phys-

4 Health education and the shaping of the body are often discussed under a Foucauldian perspective and his concept of power. I will not follow this theoretical frame here, as I am not focusing on physical education as physically hardening, normalisation or submission, nor as liberation from social constraints, but in the becoming of a school subject. In doing so, I refer to curricular frameworks like David Layton's "Science as General Education," Trends in Education 25 (1972) or Ivor F. Goodson's "Becoming a School Subject," in Subject Knowledge: Readings for the Study of School Subjects, ed. Ivor F. Goodson, Christopher J. Anstead and J. Marshall Mangan (Washington: Falmer Press, 1997).

5 Van Strien-Chardonneau, Madeleine, "Holland," in Encyclopedia of the Enlightenment, volume 1, ed. Michel Delon (London and New York: Routledge, 2002), 659.

6 See for example Barbara Helbling, Eine Schweiz für die Schule: Nationale Identität und kulturelle Vielfalt in den Schweizer Lesebüchern seit 1900 (Zürich: Chronos, 1994); Markus Furrer, Die Nation im Schulbuch - zwischen Überhöhung und Verdrängung (Hannover, Germany: Hahnsche Buchhandlung, 2004); Nathalie Dahn and Lukas Boser, "Learning to See the Nation-State: History, Geography and Public Schooling in Late 19th-Century Switzerland," Bildungsgeschichte: International Journal for the Historiography of Education 5, no. 1 (2015), 41-56; Joseph Zajda, ed., Nation-Building and History Education in a Global Culture (Dordrecht: Springer, 2015).

7 See for example David Kirk, Defining Physical Education (London: Falmer Press, 1992); Henrik Meinander, Towards a Bourgeois Manhood: Boys' Physical Education in Nordic Secondary Schools 18801940 (Helsinki: Finnish Society of Sciences and Letters, 1994); Rebekka Horlacher, "The Same but Different: The German Lehrplan and Curriculum," Journal of Curriculum Studies (2017).

8 See for example Gertrude Pfister, "Physical Activity in the Name of the Fatherland: Turnen and the National Movement (1810-1820)," Sporting Heritage 1, no. 1 (1996); Michael Krüger, "Body Culture and Nation Building: The History of Gymnastics in Germany in the period of its Foundation as a nation-State," The International Journal of the History of Sport 13, no. 3 (1996); Miklos Hadas, "The Rationalisation of the Body: Physical Education in Hungary in the Nineteenth Century," History of Education 38, no. 1 (2009); Felix Saure, "Beautiful Bodies, Exercising Warriors and Original Peoples: Sports, Greek Antiquity and National Identity from Winckelmann to 'Turnvater Jahn," German History 27, no. 3 (2009); Vincent Stolk, Willeke Los, and Wiel Veugelers, "Physical Education for 
ical education was made as a school subject of compulsory schooling and how this process of becoming a school subject transformed the notion of physical education. To do so I will focus on two agents of this process, Phokion Heinrich Clias and Adolf Spiess. Neither are seminal for the usual history of physical education like Jahn or Pehr Henrik Ling, but their writings and activities allow insights into these complex processes of changing curriculum in changing times, focusing exemplarily on Switzerland.

The first section of this article reconstructs the general history of physical education in the long eighteenth century, tracing it back to the bodily and healthy debates of child-rearing guidebooks, stressing the educational roots of (German) gymnastics compared to English sports, and making evident that after 1800 the subject of physical education changed significantly from how it was understood and taught in the seventeenth and eighteenth centuries. The second section examines the education of the 'whole body' as promoted by Adolf Spiess (1810-1858). Spiess, who had to leave reactionary Prussia in 1833 and subsequently immigrated along with many other German refugees to Switzerland, followed the German tradition of physical education. ${ }^{9}$ His concept of gymnastics was not merely physical training, but emphasised the education of the body and mind as a unified whole. The sources for this research are textbooks for physical education, guidebooks and educational writings on the importance and relevance of physical education. Spiess is prominently featured because he developed widely circulated teaching materials for physical education in compulsory schooling, initially for schools in Switzerland, but after his return to Germany for German schools as well. ${ }^{10}$ The third section uses a case study of the city of Berne to examine how physical education became part of the curriculum, using the textbooks of Phokion Heinrich Clias, one of its prominent promoters. The fourth section concludes by discussing the notion of "the citizen" as presented in the various textbooks, guidebooks and educational writings, and emphasises that the connection between physical education and nation-building is rarely discussed in the sources of the first half of the nineteenth century, not because of a failed connection between these two projects, but because they were so closely linked that their interconnection was taken for granted.

By using these types of sources, textbooks, manuals, or educational writings, the article discusses the normative level of schooling, the envisaged content of schooling

Citizenship or Humanity? Freethinkers and Natural Education in the Netherlands in the Mid-Nineteenth Century," in Sport, Health and the Body in the History of Education, ed. Mark Freeman (London and New York: Routledge, 2015). A broad variety of research deals with questions of social integration from various perspectives, see for example Marion Keim, Nation Building at Play: Sport as a tool for Social Integration in Post-Apartheid South Africa (Oxford: Meyer \& Meyer Sport, 2003); Sid Hayes and Gary Stidder, Equity and Inclusion in Physical Education and Sport: Contemporary Issues for Teachers, Trainees and Practitioners (London and New York: Routledge, 2003).

9 As a rule, the German-speaking tradition of physical education is closely connected with overall educational aspirations in general, in contrast to the Nordic tradition which emphasised more the corporal, that is the sanitary and medical, aspects of physical education (see the article by Daniel Tröhler in this issue).

10 See Adolf Spiess, Die Lehre der Turnkunst, 4 Bände (Basel: Schweighauser'sche Buchhandlung, 1840-1846); Adolf Spiess, Gedanken über die Einordnung des Turnwesens in das Ganze der Volkserziehung (Basel: Schweighauser'sche Buchhandlung, 1842); Adolf Spiess, Turnbuch für Schulen als Anleitung für den Turnunterricht durch die Lehrer der Schulen, 2 Theile (Basel: Schweighauser'sche Buchhandlung, 1847-1851). 
and an ideal notion of the future citizen. The understanding of physical education became an integral part of the compulsory school-curriculum which sought to create future citizens. On this discursive level, it can be linked to concepts like "educationalisation of the world," signifying attempts to solve social problems through education and schooling. This process was embedded in the discourse surrounding the nation-state and the meaning of national identities like "German," "Swiss" or "French," for which the army (at least for male citizens) and the school (for girls and boys) were of particular interest. ${ }^{11}$ Therefore, schooling involved more than teaching reading, writing and numeracy skills; it was (and still is) a national institution expressing its socially determined goals in the curriculum.

\section{Physical education in the educational discourse of the long eighteenth century} John Locke's Some Thoughts Concerning Education, a treatise on the education of a gentleman, ${ }^{12}$ is a major source for the educational discourse on physical education in late eighteenth century Germany - a breeding ground for physical education or Turnen to become a "normal" school subject of the curriculum. The wide dissemination of Locke's publication can be read as an expression of a specific Zeitgeist of "modernisation," even if Locke's arguments were hardly new. ${ }^{13}$ His argumentation was linked to the question of whether the cultural authority of the classics could remain relevant for the conditions of the modern gentleman; the gentleman understood here as the incorporation of the future-oriented part of the nobility, deriving its nobility not primarily from birth but from manners and conduct. ${ }^{14}$ Locke specifically enquired into the therefore appropriate forms of physical education, schooling, virtue, politics and the overall system of beliefs for raising young gentlemen in the 1700s. By questioning the cultural authority of the classics, ${ }^{15}$ Locke also called into question education and schooling at Oxford and Cambridge, the universities that

11 See for example Stephen L. Harp, Learning to be Loyal: Primary Schooling as Nation Building in Alsace and Lorraine 1850-1940 (DeKalb: Northern Illinois University Press, 1998); Daniel Tröhler, Thomas S. Popkewitz, and David F. Labaree, "Introduction - Children, Citizens, and Promised Lands: Comparative History of Political Cultures and Schooling in the Long 19th Century," in Schooling and the Making of Citizens in the Long Nineteenth Century: Comparative Visions, ed. Daniel Tröhler, Thomas S. Popkewitz, and David F. Labaree (New York: Routledge, 2011).

12 "Gentry" is, according to the Oxford English Dictionary, the term for "well-born, genteel and wellbred people" of a high social class. The term refers to a specific stratum of the English aristocracy, one whose income derives from large landholdings (landed gentry). The term "gentleman" derives as well from the term gentry and originally designated a man of the lowest rank of the English gentry, standing below an esquire and above a yeoman. The term, as it was used around 1700, had been relaxed somewhat from the strictness of this earlier designation and had come to signify a well-educated man from a good family. See also Rebekka Horlacher, The Educated Subject and the German Concept of Bildung: A Comparative Cultural History (New York: Routledge, 2016), 19-21.

13 Locke himself emphasised his argument's novelty against conceptions of the "usual," "common," or "ordinary education;" see Nathan Tarcov, Locke's Education for Liberty (Chicago: University of Chicago Press, 1984), 80.

14 How to become (intellectually and morally) a gentleman was, for example, described in the 1711 first edition, Characteristics of Men, Manners, Opinions, Times by Anthony Ashley Cooper, third Earl of Shaftesbury; see Lawrence E. Klein, Shaftesbury and the Culture of Politeness (Cambridge: Cambridge University Press, 1994).

15 A prominent treatment was Jonathan Swift's Battle of the Books (1704); the most famous debate on this topic took place at the court of Versailles in the so-called Quarrel of the Ancients and the Moderns during the last fifteen years of the seventeenth century. 
were the traditional places of study for the English nobility and upper bourgeoisie. ${ }^{16}$ The "modern" aspect of Locke's treatise lies in his answer regarding both who was responsible for education and schooling and how his "being a gentleman" was doable.

Locke's Some Thoughts Concerning Education was addressed to Locke's close friend Edward Clarke (1650-1710), a member of parliament who had asked himLocke was a trained paediatrician-for advice on raising his son. After a dedicatory letter explaining the origins of the treatise, the book comprises 202 paragraphs starting with subjects such as air and alteration and proceeding through topics such as goblins, wisdom, and writing. The first paragraph outlines some of Locke's fundamental assumptions about education, merging body and mind: "A Sound Mind in a sound Body, is a short, but full description of a Happy State in this World [...] He, whose Mind directs not wisely, will never take the right Way; and he, whose Body is crazy and feeble, will never be able to advance in it."

In Locke's understanding, the importance of education could not be overestimated: "Even if some 'natural Genius' are vigorous and well framed by Nature [...] Nine parts of Ten are what they are, Good or Evil, useful or not, by their Education." ${ }^{17}$ Consistent with this idea regarding the importance of education and Locke's idea of human nature being largely a "blank slate" or a "tabula rasa," a substantial part of his treatise examines the education of the body, or is at least devoted to the bodily parts of education like "craving," "punishment," or "beating," and argues for the importance of health for "Business and Happiness." As all human knowledge and skills have to be learned, it was critical to provide a healthy environment and proper incentives. "How necessary Health is [...] is too obvious to need any Proof," was Locke's simple justification for its importance. ${ }^{18}$

It was precisely this "modernist" aspect of Locke's curricular argument with regard to the future ideal 'citizen' that became - two or three decades before Jahn's nationalist and attention-grabbing advocacy for Turnen — so pivotal for the subsequent reception of his work among the German philanthropists, a group of intellectuals and practical educators seeking to offer "modern" schooling to the emerging bourgeoisie; these developments then functioning by that as pioneers for physical education as modern school subject. ${ }^{19}$ This group of educators opened boarding schools with a "modern" curriculum and published books to disseminate their "new" education, discussing publically and at length essential books on education, among them: Rousseau's Emile and John Locke's Some Thoughts Concerning Education. ${ }^{20}$ Hence, gymnastics was offered in these new boarding schools as a regular course, also in-

16 As these universities pursued a traditional curriculum, the "modern" sciences, and various new forms of disciplinary knowledge, were being developed in scholarly societies and academies, such as the Royal Society which had been founded in 1660.

17 John Locke, Some Thoughts Concerning Education (London: A. and J. Churchill, 1693), 1-2.

18 Locke (1693), 3.

19 Rebekka Horlacher, “Wie aus 'einigen Gedanken' ein 'Handbuch' wurde. Die Locke-Rezeption der Philanthropen," in Die Leidenschaft der Aufklärung: Studien über Zusammenhänge von bürgerlicher Gesellschaft und Bildung, ed. Jürgen Oelkers and Daniel Tröhler (Weinheim: Beltz, 1999).

20 The philanthropists also published a 16-volume book series titled Allgemeine Revision des gesammten Schul- und Erziehungswesens. The 9th volume (1787) contained an annotated translation of Locke's Thoughts. The Allgemeine Revision claimed to contain all practical and useful educational knowledge. In doing so, the philanthropists pursued similar goals as Locke's Thoughts, even if the philosophical spectrum of the philanthropists is not comparable to Locke's theory of mind. 
spired by the curriculum of knight's academies, where the traditional subjects of the courtly traditions were taught: vaulting, dancing, fencing, manners, ${ }^{21}$ and various manual skills ${ }^{22}$ that were united to create the "competencies" necessary for the conduct of a "good life." ${ }^{23}$ Even if the subjects taught have been still largely inspired by the courtly tradition, an "educationalised" meaning of gymnastics became obvious, ${ }^{24}$ as the example of one prominent proponent of this "new" physical education as a school subject, the German philanthropist Johann Christoph Friedrich GutsMuths (1759-1839) shows. GutsMuths worked as a tutor for a wealthy family before becoming a teacher at the Schnepfenthal Salzmann School, one of the famous German boarding schools of that time and part of the philanthropic movement, to which the founder of the school, Christian Gotthilf Salzmann, also belonged. ${ }^{25}$ At the Schnepfenthal Salzmann School, GutsMuths developed a specific type of gymnastics with an understanding of gymnastics as an educational topic which referred to a specific understanding of "initial nature" and was strictly opposite to an understanding of physical education as a soulless shaping of the body or as pure competition. In doing so, he moved the subject from the courtly tradition towards a more systematic analysis of the body. In an essay from 1793 titled Gymnastics for the Youth, GutsMuths wrote: "Let us harden the body, then it gets more duration and strong nerves; let us train the body, then it gets powerful and active; it will stimulate the mind then, making it masculine, powerful, tireless, firm, and full of courage." ${ }^{26}$ Hence, the body was not just an unimportant physical shell, nor was it a threat to one's moral integrity as it was under the doctrine of original sin. The body was rather seen as amenable to

21 Christiane Eisenberg, "English Sports" und deutsche Bürger: Eine Gesellschaftsgeschichte 1800-1939 (Paderborn: Schöningh, 1999), 97.

22 Hanno Schmitt, "Die Anfänge des Schulsports im 18. Jahrhundert," in Vernunft und Menschlichkeit: Studien zur philanthropischen Erziehungsbewegung (Bad Heilbrunn: Klinkhardt, 2007), 209.

23 The question of how to prepare people to conduct a "good life" was also the main topic of the somehow competing boarding school of Johann Heinrich Pestalozzi in Switzerland and of his educational pedagogy. Pestalozzi's ideas were developed in various essays and implemented in his institutions located in Burgdorf, Münchenbuchsee and Yverdon; see Daniel Tröhler, Pestalozzi and the Educationalization of the World (New York: Routledge, 2013). Even if Pestalozzi didn't consider physical education to be the main topic of his education, and even though Pestalozzi's institute lagged behind other boarding schools' physical education curriculum, regular exercises, such as swimming in the summer and skating in the winter, were part of the daily curriculum; see Johann Heinrich Pestalozzi, "Über Körperbildung als Einleitung auf den Versuch einer Elementargymnastik, in einer Reihenfolge körperlicher Übungen, Juni/Juli 1807," in Pestalozzi Sämtliche Werke, 20. Band (Zürich: Orell Füssli, 1963), 47; see Emanuele Isidori, "Pestalozzi e l'educazione del corpo: Attualità di una pedagogia," Rivista Formazione Lavoro Persona 7, no. 21 (2017), 77-89.

24 The hygienic aspect of physical education was addressed at the same time by Johann Peter Frank in the second volume of his System einer vollständigen medicinischen Polizey (Mannheim: Schwan, 1780 ), arguing against a to early tension of the juvenile "soul- and bodily forces" (Nina Balcar, "Psychopathische' Schuljugend in Deutschland. Eine Debatte zwischen Psychiatern und Pädaogen im späten Kaiserreich," Bildungsgeschichte: International Journal for the Historiography of Education 7, no. 2 (2017), 158).

25 Salzmann had been, in 1787, one of the annotators of the translation of John Locke's Some Thoughts Concerning Education; Joachim Heinrich Campe ed., Allgemeine Revision des gesammten Schul- und Erziehungswesens von einer Gesellschaft practischer Erzieher, Neunter Theil (Wien and Wolfenbüttel: Rudolph Grässer und Schulbuchhandlung, 1787).

26 "Lasst uns den Körper mehr abhärten, so wird er mehr Dauer und Nervenstärke erhalten; lasst uns ihn üben, so wird er kraftvoll und thätig werden; dann wird er den Geist beleben, ihn männlich, kraftvoll, unermüdlich, standhaft und muthvoll machen." Johann Christoph Friedrich GutsMuths, Gymnastik für die Jugend: Enthalten eine praktische Anweisung zu Leibesübungen (Schnepfenthal: Verlage der Buchhandlung der Erziehungsanstalt, 1793), 140. 
educational intervention, as an integral part of the human individual and therefore open to but also requiring education.

GutsMuths' work on the body was not only qualitatively different from the courtly tradition with its emphasis on fencing, dancing or horseback-riding, but was also connected to a specific notion of "being German." ${ }^{27}$ GutsMuths stated: "There is a big difference between learning to dance and the education of the body, between its graceful attitude and nervousness, between a timid spirit of a young gentleman and the masculine nature of a German young man." ${ }^{28}$ Hardening, training, and the stimulation of the German masculine mind were also intended to create a contrast with a purely outer "French" notion of the body. The respective exercises necessary to create this new type of German citizen had to be oriented towards the human "initial nature" and the characteristics of "primitive people." 29 Thus, a specific notion of nature was evoked, a notion of purity, unaffectedness and virginity; yet, this notion of an "initial nature" was largely imagined. Consistent with certain cultural-critical discourses within the German Enlightenment-for example, the work of Johann Gottfried Herder - notions of the "primitive people" and their "initial nature" were synonyms for the unity of mind and body, untouched by artificial civilization. ${ }^{30}$

However, according to GutsMuths, this particular conception of nature became part of the education of the soul, and was improperly isolated from the education of the body. It seems, GutsMuths further noted, "as if the soul had no body." ${ }^{1}$ This is why children's physical activities, their games and playing, were often "dangerous for their health and their lives," and constituted a wasteful form of "leisure and not physical exercises under careful control." 32 In his writings, GutsMuths sought to systematically arrange and justify distinct exercises and the concept of physical hardening in order to popularise them "for the merit of my whole nation." ${ }_{33}$ Thus physical exercises and gymnastics became more than a simple school subject, they became an integral part of the fabrication of the future German citizen.

GutsMuths' writings stimulated other educational writings, and he became a seminal author in discourses on physical education, schooling and curriculum. ${ }^{34}$ One of

27 In line with the dissemination of the notion of nation after the defeat of the German troops by Napoelon in 1806, this national aspect got stronger in GutsMuths' Gymnastics book for the sons of the Fatherland (Turnbuch für die Söhne des Vaterlandes, 1817).

28 "Es ist aber ein sehr großer Unterschied zwischen Tanzen lernen und Ausbildung des Körpers, zwischen zierlicher Haltung und Nervosität desselben, zwischen dem zaghaften Geiste des jungen Elegants und dem männlichen Wesen des deutsch seyn sollenden Jünglings." GutsMuths (1793), 16.

29 GutsMuths (1793), 3.

30 It was precisely this notion of nature that seemed to be found in Rousseaus's work. In emphasising this notion, a (still) dominant strand of the German reception of Rousseau neglected Rousseau's initial statement, that his emphasis for natural education, as proposed in Emile, was a temporary solution in light of the corrupt French society and did not constitute an aspired end-goal; see Rebekka Horlacher, "Der Rousseau der Erziehungswissenschaft," in Zwischen Vielfalt und Imagination. Praktiken der Jean-Jacques Rousseau Rezeption / Entre hétérogénéité et imagination. Pratiques de la réception de Jean-Jacques Rousseau, ed. Jesko Reiling and Daniel Tröhler (Geneva: Éditions Slatkine, 2013).

31 GutsMuths (1793), 12

32 GutsMuths (1793), 14.

33 GutsMuths (1793), 143.

34 See e.g. Henning Eichenberg "Body Culture and Democratic Nationalism: Popular Gymnastics' in Nineteenth-Century Denmark," The International Journal of the History of Sport 12, no. 2, (1995), 109. 
his successors who also promoted physical education was Jahn, who explicitly and in a populist way connected gymnastics to nationalist politics. Jahn's movement was quickly placed under governmental surveillance due to the revolutionary potential of its ideology. Jahn's conception of physical education was so controversial that by 1820 his movement had become politically disreputable. Indeed, it was only after the Prussian King Friedrich Wilhelm IV (1795-1861) ascended the throne in 1840 that the so-called Turnsperre, the ban on any gymnastic movement within the German Confederation (1815-1866), was revoked. Two years later, in 1842, the King issued a cabinet order implementing mandatory gymnastics training in schools for boys. ${ }^{35}$ However, in doing so, the Prussian King explicitly dissociated himself from Jahn's notion of gymnastics and criticised its physical and moral disadvantages. Friedrich Wilhelm's goal was not free gymnastics (Freiübungen), which was the main concept of gymnastics that Jahn had promoted, but a form of gymnastics that sought to create a "harmonious education of hard working sons of the fatherland," 36 as he proclaimed in a corresponding resolution issued in 1844. The associated exercises Friedrich Wilhelm endorsed did not only seek to strengthen the students' physical capabilities, but also sought to enhance their conduct, and the expression and smoothness of their movement, to support their military strength. It was precisely this combination of physical education and military exercise that became the dominant argument for education policy to include this new school subject. But how became Jahn's notion of physical education politically acceptable? How was his concept of gymnastics transformed to and reshaped for pedagogical purposes and settings?

\section{Spiess' notion of physical education and the role of schooling}

Based on GutsMuths' writings and also trained by Jahn, Adolf Spiess focused on establishing gymnastics as a mandatory school subject. Spiess, a Lutheran theologian, member of a fraternity, and acquainted with leaders of the nationalistic German gymnastic movement, started his career in Switzerland in 1833: first as private tutor, then as teacher in Burgdorf, and later as a teacher for gymnastics and history at the secondary school for girls in Basel. During his fifteen years in Switzerland, Spiess published several books on the objectives and uses of gymnastics in schools and their pedagogical implementation for both sexes, whereby he differentiated according to the school tracks. ${ }^{37}$

Based on his successful initiatives and due to his textbooks, Spiess is one of the "founders" of physical education as a distinct school subject-not only in Switzerland. Spiess' notion of physical education - in line with the German tradition of gymnastics (Turnen)_did not focus on competitions or on "sports" as part of leisure activities. ${ }^{38}$ For his textbooks, Spiess refined Jahn's physical exercises, developed in Berlin at the Hasenheide Park and spread all over Europe through the instructions

35 Filip Bláha, Frauenkörper im Fokus: Wahrnehmung zwischen Strasse und Turnplatz in Prag und Dresden vor dem Ersten Weltkrieg (Frankfurt am Main: Peter Lang, 2013), 158.

36 Friedrich Wilhelm IV, König von Preussen. “Ministerialverfügung vom 7. Februar 1844," in Altes und Neues vom Turnen, Heft 1, ed. Hans Ferdinand Massmann (Berlin: Hermann Schultze, 1849), 80.

37 Spiess (1842), 7.

38 For sports as leisure activity see e.g. Norbert Elias and Eric Dunning, Quest for Excitement: Sport and Leisure in the Civilizing Process (Oxford: Basil Blackwell, 1986). 
of how to build a Jahnish playground, ${ }^{39}$ and developed a set of gymnastic movements independent of any gymnastic equipment. ${ }^{40}$ This notion of gymnastics became part of the curriculum in several European countries in the second half of the nineteenth century.

Spiess' writings focussed on the body as an instrument of the mind, for which he was later criticised as having endorsed soulless rote drills. ${ }^{41}$ In his Thoughts on the Classification of Gymnastics Within the System of Mass Education (1842), Spiess emphasised that the body educates the mind, and proclaimed that the outer physical shape is a mirror of the inner soul. ${ }^{42}$ This notion of inner soul and outer shape relates to GutsMuths' notion of working on the body and conceptualises physical education as part of the body-building process akin to the nation-building process. This parallelism between the education of the individual and construction of the nation was explicitly emphasised. Spiess' essay was a seven-point justification of the importance of gymnastics as a school subject. He described not only why the existing public playgrounds were not adequate for this task, but also how school playgrounds had to be equipped, how the associated curricula and tests should be designed, and how teachers should be trained. Moreover, Spiess declared gymnastics - in line with the argumentation of the Prussian King - to be a pre-school for military service, thus giving another reason why this subject had to be taught in the compulsory schools. ${ }^{43}$

For Spiess gymnastics was a necessary part of compulsory schooling especially if compulsory schooling aimed at "educating the youth towards the community and the nation." 44 For him, the main advantage of making gymnastics a part of the curriculum was that it offered a structured, supportive, and controlled proceeding of physical education, while unstructured gymnastics performed on a public playground would largely be random. ${ }^{45}$ The subject itself had to be taught in a way that was easily accessible, ${ }^{46}$ and its relationship to other subjects had to be considered. ${ }^{47}$

The curriculum differed according to the related strands of schooling and had a broad range. In elementary urban schools, standing, walking, and hopping were taught, as well as climbing, hanging, and arm-wrestling, several ways of running and jumping, marching, games, swimming and skating, if possible. ${ }^{48}$ All these ways to move were closely connected to time and rhythm, dance and singing. In secondary schools the curriculum was similar but more advanced and clearly more oriented towards military preparation and "military drill." ${ }^{49}$ Education for girls differed from

39 Friedrich Ludwig Jahn and Ernst Eiselen, Die deutsche Turnkunst zur Einrichtung der Turnplätze (Berlin: Kosten der Herausgeber, 1816).

40 Robert Prohl, Grundriss der Sportpädagogik 1999 (Wiebelsheim: Limpert, 2010), 39.

41 Bláha (2013), 159.

42 Spiess (1842), III.

43 In line with this argumentation, physical education became a mandatory school subject in Switzerland in 1874. Contrary to the cantonal sovereignty of school laws in Switzerland, physical education remains regulated by federal law.

44 Spiess (1842), 1.

45 Spiess (1842), 2-5.

46 Spiess (1842), 6.

47 Spiess (1842), 7.

48 Spiess (1842), 8.

49 Spiess (1842), 9. 
that of boys, especially at the secondary level. According to their female nature, girls' gymnastics focussed more on 'pleasing movements' unrelated to skipping, jumping, running, working with weights, dancing and singing. ${ }^{50}$ The curriculum for rural boys' and girls' schools was further reduced. Here, gymnastics were focussed on their relation to living conditions and were preliminary preparation for future military service or - in the case of girls - were exercises, dancing, and singing. ${ }^{51}$

The introduction of gymnastics into the curriculum also required properly educated gym teachers. Once again, Spiess emphasised that physical education was not a supplementary or optional part of schooling, but an integral part of any appropriate education. Physical education required special spaces and playgrounds, and had to be appropriately placed in the curriculum. Even if the curriculum of gymnastics focussed on physical movement, the appropriate education of the teachers was much broader. Teachers were not simply trained in physical education, but also in dietetics, which placed them in a position mediating between ordinary teachers and medical doctors, and connecting the latter closer to schooling. ${ }^{52}$ Similar to the long eighteenth century, when paediatricians figured as the main authors of educational support literature, medical doctors became-via physical education and its increasing orientation towards the physical aspects of the body and gymnastics - authorities in the educational discourse, perhaps even anticipating the medicalisation of everyday life, society ${ }^{53}$ and educational research. ${ }^{54}$

\section{How physical education became a school subject: The example of Berne}

On 10 September 1804, in the middle of the post-revolutionary Helvetic Republic and during a time of various school reform projects in Switzerland aiming at the creation of the later established, state-founded, legally-defined, and public compulsory schooling, ${ }^{55}$ the Bernese government established a commission for the reorganisation of curriculum and schooling. One year later, the commission presented a corresponding proposal calling for organising Berne's public schools along two related lines, an upper and a lower, with the upper strand being supplemented by a voluntary evening school where dancing, fencing and swimming were taught. ${ }^{56}$ While the swimming facilities and fencing halls already existed, the education of teachers for these activities exhibited various shortcomings. After some discussion regarding the necessity of physical education in the curriculum, and the importance of specialised training for teachers for these subjects, Phokion Heinrich Clias (1782-1854) was, in 1818 , made officially responsible for physical education in the city schools. ${ }^{57}$

50 Spiess (1842), 10.

51 Spiess (1842), 11.

52 Spiess (1842), 19.

53 See Peter Conrad, The Medicalization of Society (Baltimore: Johns Hopkins University Press, 2007); Thomas Szasz, The Medicalization of Everyday Life (Syracuse: University Press, 2007).

54 See Daniel Tröhler, "The medicalization of current educational research and its effects on education policy and school reforms," Discourse: Studies in the Cultural Politics of Education 36, no. 5 (2015).

55 Rebekka Horlacher, "Mehr als eine Vorgeschichte. Schule im langen 18. Jahrhundert," in Bildungsgeschichte Schweiz [working title], ed. Lucien Criblez et al. (Zurich: Chronos, 2018).

56 Ernst Strupler, Die Anfänge der modernen Leibesübungen in der Schweiz bis 1833 (Winterthur: P. G. Keller, 1955), 33-4.

57 Phokion Heinrich Clias, Anfangsgründe der Gymnastik oder Turnkunst (Bern: J. J. Burgdorfer, 1816), 36 . 
Clias, the son of Swiss immigrants to the United States, was born in Boston during the American War of Independence and named after the Athenian politician who believed that extreme frugality was the condition for virtue. After the death of his mother, his father, who had been an officer in the American War of Independence, sent him to a boarding school in the Netherlands. Clias soon left the school and travelled across Europe, starting his professional career as private tutor in the Netherlands and Germany before moving to Switzerland to become a teacher and working at the institute of Philipp Emanuel von Fellenberg (1771-1844) in Hofwyl near Berne. In 1822, Clias became superintendent of physical training for the Royal Military and Naval Academies in England and opened a private gymnasium in London. He owed this appointment to his personal acquaintance with the British ambassador to Switzerland who had asked him to work with his hydrocephalic son. ${ }^{58}$ The medical aspects of physical education were subsequently integrated into Clias' teaching. After his time in England, he moved back to the continent, became a member of the Bernese parliament (1832-1835) and lived partly in France before moving back to Switzerland in 1848 where he died in 1854 following complications from an accident.

Clias clearly presented the value of physical education in his writings as early as 1816. In a book titled Elements of Gymnastics and Physical Education, he sought to convince the Bernese government and public of physical education's importance and presented himself as being uniquely capable of introducing physical education into Bernese schools. Clias' experiences as an officer in the Bernese army led him to become concerned about soldiers' inactivity and the resulting risk of their demoralisation. He argued that physical education supported the creation of a national identity that did not require a shared language, religious affiliation or ethnicity-concepts that Clias believed were not applicable to the case of Switzerland. ${ }^{59}$ Regarding recent German history and Jahn's writings, Clias claimed that the Swiss Confederates' heroism allowed them to defeat any well-trained army and therefore had to be taken into account as important concepts for any nation-building project. He stated:

The thunderclouds, which hovered over our heads during the general storm; the inner strength and the awakening of a nation languishing under an iron yoke, its rapid victories, its military glory and the restoration of its customs, - all these are examples and earnest warnings for carefully safeguarding the physical education of a people, who have always been characterized by strength, courage, and fidelity. ${ }^{60}$

The relationship between the nation and physical education is discussed even more explicitly in a footnote to the heading of "nation." Clias referred here to Jahn who

58 Jan Todd, Physical Culture and the Body Beautiful: Purposive Exercise In the Lives of American Women 1800-1870 (Macon: Mercer University Press, 1998), 37.

59 Jean-Claude Bussard, L'éducation physique suisse en quête d'identité (1800-1930) (Paris: L'Harmat$\tan , 2007), 65$.

60 "Die Gewitterwolken, welche während dem allgemeinen Sturme über unsern Häuptern schwebte; die innere Kraft und das Aufwachen einer Nation, die unter einem eisernen Joche schmachtete, ihre raschen Siege, ihr kriegerischer Ruhm und die Wiederherstellung ihrer Sitten, - alles dieses sind eben so viele Beyspiele und ernste Ermahnungen, mit Sorgfalt über die physische Erziehung eines Volks zu wachen, welches durch Stärke, Muth und Treue sich immer ausgezeichnet hat." Clias (1816), 1-2. 
is described as someone "whose influence on these exercises greatly contributed to instilling this nation with the patriotic spirit and physical endurance it needed to free itself from the slavery under which it was suffering." ${ }^{61}$ In this sentence, Clias closely connects physical education, military strength and national consciousness. Similar to Anton Santesson's references to the glorious military victories of the Swedish army, described in Johannes Westberg's article in this special issue, Clias referred to the heroic acts of the Swiss Confederates of the glorious past, without referring to a concrete war or event. He labelled them "as a handful of shepherds" who resisted "large military force" and resist a "large military force," like a ["real"] nation would, "even if its barely the size of a province."

According to this argument, physical education became a requirement in order for the nation to successfully exercise sovereignty, regardless of whether the concepts of the nation or the sovereignty were the same. Besides the corporal advantages it offered, physical education also had moral advantages, as it resulted in "an enduring serenity of the mind and the soul as a fruit of the physical health of the body." ${ }^{63}$ Clias emphasised even more than either GutsMuths or Jahn the anatomical and physiological aspects of gymnastics, which became even more marked as he became older. ${ }^{64}$ Clias' notion of physical education was thereby twofold: it aimed at military strength and national cohesion in a state not able to refer to shared language or culture and supported moral education following an understanding of the close entanglement of body and soul.

\section{Physical education and nation-building in Switzerland}

As described in the first section of this article, physical education was not a completely new topic around 1800. It referred to existing traditions and practices of upbringing and medical knowledge that already existed in several advisory books, but sought to fill them with new content. Based on ideas and publications like Locke's, reflecting the impact of knowledge from physical anthropology and the medical sciences, the physical condition of children became an educational and pedagogical topic. ${ }^{65}$ Hence, Spiess' and Clias' writings encountered a fertile audience. They took up existing knowledge and offered a systematic overview of what had to be done to fully integrate physical education into the curriculum. Using existing traditions and discourses, Spiess, in particular, developed a syllabus for physical education, comparable to other syllabi, in the unique context of establishing compulsory schooling. Switzerland may have been even a particular stimulating context in this respect, as

61 "Der Einfluss dieser Uebungen haben mächtig dazu beygetragen, dieser Nation jenen patriotischen Geist und die körperliche Ausharrung mitzutheilen, dessen sie bedurfte, um sich von der Sklaverey, unter welcher sie seufzte, zu befreyen." Clias (1816), 1.

62 "Eine Handvoll Hirten konnten ein zahlreiches und geübtes Heer besiegen wie eine Nation, deren Land kaum einer Provinz eines grossen Reichs gleich kommt, Mächten widerstehen, welche durch ihre Siege und die Zahl ihrer Krieger furchtbar waren." Clias (1816), 2-3.

63 Clias (1816), 23.

64 Strupler (1955), 73. His Elements of Gymnastics and Physical Education (1816) was followed by six chapters (20 pages) explaining the body's structure.

65 See Carsten Zelle, ed, "Vernünftige Ärzte:" Hallesche Psychomediziner und die Anfänge der Anthropologie in der deutschsprachigen Frühaufklärung (Tübingen: Max Niemeyer, 2001); Jörn Garber, "Einleitung," in "Die Stammutter aller guten Schulen:" Das Dessauer Philanthropinum und der deutsche Philanthropismus 1774-1793, ed. Jörn Garber (Tübingen: Max Niemeyer, 2008), 7. 
some argue, for the remoteness of the country facilitated the preservation of early modern traditions of popular games, offering a reference point for physical education and for a discourse based upon the unspoiled natural purity of the Swiss countryside and the Swiss Alps. ${ }^{66}$

However, physical exercises did not just seek to strengthen the body's abilities; it sought to gain something "further." This "further" was the health-maintaining effect for the body and soul, which were connected to the idea of the nation and its strength. A well-trained body revealed a proper soul and helped express, and perhaps served to worship, the idea of the nation. Even though the German gymnastics movement that provided the ideological context Spiess grew up in had emphasised the German nation as the ideological concept, Spiess and his contemporaries in Switzerland and Europe, here exemplified by Clias, adapted the German concept of physical education to local circumstances and ideologies. A benefit in this respect was the fact that mass schooling, the method for fabricating future citizens, requested an increasing demand for teaching material focussed on physical education. Spiess filled this gap with his writings and guidance regarding the new subject.

The fact that Spiess' teaching materials were used in countries with contexts as different as Switzerland and Germany, and were also translated into French, might indicate the ideological openness, or undifferentiated nature, of the notion of the nation as expressed in Spiess' textbooks. These textbooks introduced a pedagogicaland no longer a political — understanding of physical education, a concrete syllabus, and lesson planning. In this respect, physical education and nation-building were less oriented to the national tradition and idiosyncrasy than to the physical education promoted by Jahn. The national tradition following Jahn was ambiguous due to its real or just assumed revolutionary potential and therefore not the appropriate notion of physical education in the context of schooling of the emerging nation-states. Nevertheless, there was no need for Spiess to explicitly present his books as being relevant for nation-building because this task had already been accomplished by various education laws providing a legal basis for public schooling and codifying a shared understanding of its role and aims. ${ }^{67}$ On the basis of schooling as part of the educationalisation of the world, the purpose of Spiess' teaching materials was merely to provide guidelines for lesson planning.

The shift that occurred in the educational discourse, from the relation between physical education and nation-building to the pedagogical requirements of physical education and a stronger focus on health education and hygiene, is remarkable. ${ }^{68}$ This discourse subsequently became dominant in the context of schooling, reintegrating medical doctors into education and schooling, while the discourse on physical strength became less prominent and shifted towards a strictly military discourse. ${ }^{69}$

The often-quoted historiographic connection between physical education, mil-

66 Strupler (1955), $1-5$.

67 Daniel Tröhler, "Curriculum History, or the Educational Construction of Europe in the Long 19th Century," European Educational Research Journal 15, no. 3 (2016).

68 See for example Michèle Hofmann, "Ärztliche Macht und ihre Einfluss auf den Schulalltag in der Schweiz im ausgehenden 19. und beginnenden 20. Jahrhundert," Paedagogica Historica 51, no. 1-2 (2015).

69 See the article of Ingrid Brühwiler in this special issue. 
itary service and nation-building is, against this backdrop, not false, but curtails a much more complex and interwoven history. In particular, the understanding of this topic must be contextualised by shedding light on its various political and social entanglements, for only then can we appreciate its broader meaning as a school subject. The transformation of physical education into a school subject is consequently not only the implementation of a new subject into the curriculum but also the success story of solving social problems and building the future citizen through education. 


\section{References}

\section{Sources}

Campe, Joachim Heinrich, ed. Allgemeine Revision des gesammten Schul- und Erziehungswesens von einer Gesellschaft practischer Erzieher, Neunter Theil. Wien and Wolfenbüttel: Rudolph Grässer und Schulbuchhandlung, 1787.

Clias, Phokion Heinrich. Anfangsgründe der Gymnastik oder Turnkunst. Bern: J. J. Burgdorfer, 1816.

Frank, Johann Peter. System einer vollständigen medicinischen Polizey, volume 2. Mannheim: Schwan, 1780.

Friedrich Wilhelm IV., König von Preußen. "Ministerialverfügung vom 7. Februar 1844." In Altes und Neues vom Turnen, Heft 1, edited by Hans Ferdinand Massmann, 80-6. Berlin: Hermann Schultze, 1849.

GutsMuths, Johann Christoph Friedrich. Gymnastik für die Jugend: Enthalten eine praktische Anweisung zu Leibesübungen. Schnepfenthal: Verlage der Buchhandlung der Erziehungsanstalt, 1793.

Jahn, Friedrich Ludwig, and Ernst Eiselen. Die deutsche Turnkunst zur Einrichtung der Turnplätze. Berlin: Kosten der Herausgeber, 1816.

Locke, John. Some Thoughts Concerning Education. London: Printed for A. and J. Churchill, at the Black Wan in Paternoster-row, 1693.

Pestalozzi, Johann Heinrich. "Über Körperbildung als Einleitung auf den Versuch einer Elementargymnastik, in einer Reihenfolge körperlicher Übungen." In Pestalozzi Sämtliche Werke, Band 20, 45-68. Zürich: Orell Füssli, 1963.

Spiess, Adolf. Die Lehre der Turnkunst, 4 Bände. Basel: Schweighauser'sche Buchhandlung, 1840-1846.

Spiess, Adolf. Gedanken über die Einordnung des Turnwesens in das Ganze der Volkserziehung. Basel: Schweighauser'sche Buchhandlung, 1842.

Spiess, Adolf. Turnbuch für Schulen als Anleitung für den Turnunterricht durch die Lehrer der Schulen, 2 Theile. Basel: Schweighauser'sche Buchhandlung, 18471851.

\section{Literature}

Balcar, Nina. "Psychopathische' Schuljugend in Deutschland. Eine Debatte zwischen Psychiatern und Pädagogen im späten Kaiserreich." Bildungsgeschichte: International Journal for the Historiography of Education 7, no. 2 (2017), 157-72.

Bláha, Filip. Frauenkörper im Fokus: Wahrnehmung zwischen Straße und Turnplatz in Prag und Dresden vor dem Ersten Weltkrieg. Frankfurt am Main: Peter Lang, 2013.

Bussard, Jean-Claude. L'éducation physique suisse en quête d'identité (1800-1930). Paris: L'Harmattan, 2007.

Conrad, Peter. The Medicalization of Society. Baltimore: Johns Hopkins University Press, 2007.

Dahn, Nathalie, and Lukas Boser. "Learning to See the Nation-State: History, Geography and Public Schooling in Late 19th-Century Switzerland." Bildungsgeschichte: International Journal for the Historiography of Education 5, no. 1 (2015), 41-56.

Eichenberg, Henning. "Body Culture and Democratic Nationalism: Popular Gymnastics' in Nineteenth-Century Denmark." The International Journal of the History of Sport 12, no. 2, (1995), 108-24. 
Eisenberg, Christiane. "English Sports" und deutsche Bürger: Eine Gesellschaftsgeschichte 1800-1939. Paderborn: Schöningh, 1999.

Elias, Norbert, and Eric Dunning. Quest for Excitement: Sport and Leisure in the Civilizing Process. Oxford, and New York: Basil Blackwell, 1986.

Furrer, Markus. Die Nation im Schulbuch - zwischen Überhöhung und Verdrängung. Hannover: Hahnsche Buchhandlung, 2004.

Garber, Jörn. "Einleitung." In "Die Stammmutter aller guten Schulen:” Das Dessauer Philanthropinum und der deutsche Philanthropismus 1774-1793, edited by Jörn Garber, 1-22. Tübingen: Max Niemeyer, 2008.

Goodson, Ivor F. "Becoming a School Subject." In Subject Knowledge: Readings for the Study of School Subjects, edited by Ivor F. Goodson, Christopher J. Anstead, and J. Marshall Mangan, 20-37. Washington: Falmer Press, 1997.

Harp, Stephen L. Learning to be Loyal: Primary Schooling as Nation Building in Alsace and Lorraine 1850-1940. DeKalb: Northern Illinois University Press, 1998.

Hayes, Sid and Gary Stidder, Equity and Inclusion in Physical Education and Sport: Contemporary Issues for Teachers, Trainees and Practitioners. London and New York: Routledge, 2003.

Helbling, Barbara. Eine Schweiz für die Schule: Nationale Identität und kulturelle Vielfalt in den Schweizer Lesebüchern seit 1900. Zurich: Chronos, 1994.

Hofmann, Michèle. "Ärztliche Macht und ihre Einfluss auf den Schulalltag in der Schweiz im ausgehenden 19. und beginnenden 20. Jahrhundert.” Paedagogica Historica 51, no. 1-2 (2015), 88-103.

Horlacher, Rebekka. “Wie aus 'einigen Gedanken' ein 'Handbuch' wurde: Die Locke-Rezeption der Philanthropen.” In Die Leidenschaft der Aufklärung: Studien über Zusammenhänge von bürgerlicher Gesellschaft und Bildung, edited by Jürgen Oelkers and Daniel Tröhler, 85-101. Weinheim: Beltz, 1999.

Horlacher, Rebekka. "Der Rousseau der Erziehungswissenschaft." In Zwischen Vielfalt und Imagination: Praktiken der Jean-Jacques Rousseau Rezeption / Entre hétérogénéité et imagination: Pratiques de la réception de Jean-Jacques Rousseau, edited by Jesko Reiling and Daniel Tröhler, 241-62. Geneva: Éditions Slatkine, 2013.

Horlacher, Rebekka. The Educated Subject and the German Concept of Bildung: A Comparative Cultural History. New York: Routledge, 2016.

Horlacher, Rebekka. "The Same but Different: The German Lehrplan and Curriculum." Journal of Curriculum Studies (published online, 2017).

Horlacher, Rebekka. "Mehr als eine Vorgeschichte: Schule im langen 18. Jahrhundert." In Bildungsgeschichte Schweiz [working title], edited by Lucien Criblez et al. (in preparation). Zurich: Chronos, 2018.

Keim, Marion. Nation Building at Play: Sport as a tool for Social Integration in Post-Apartheid South Africa. Oxford: Meyer \& Meyer Sport, 2003.

Kirk, David. Defining Physical Education: The Social Construction of a School Subject in Postwar Britain. London: Falmer Press, 1992.

Isidori, Emanuele. "Pestalozzi e l'educazione del corpo: attualità di una pedagogia." Rivista Formazione Lavoro Persona 7, no. 21 (2017), 77-89.

Klein, Lawrence E. Shaftesbury and the Culture of Politeness. Cambridge: Cambridge University Press, 1994. 
Kruger, Michael. "Body Culture and Nation Building: The history of Gymnastics in Germany in the Period of Its Foundation as a Nation-State." The International Journal of the History of Sport 13, no. 3, (1996), 409-17.

Layton, David. "Science as General Education." Trends in Education 25 (1972), 1115.

Meinander, Henrik. Towards a Bourgeois Manhood: Boys' Physical Education in Nordic Secondary Schools 1880-1940. Helsinki: Finnish Society of Sciences and Letters, 1994.

Mercier, Roger. L'enfant dans la société du XVIIle siècle. Dakar: Université de Dakar, 1961.

Naul, Roland. "History of sport and physical education in Germany, 1800-1945." In Sport and Physical Education in Germany, edited by Ken Hardman and Roland Naul, 15-27. London: Routledge, 2002.

Pfister, Gertrude. "Physical Activity in the name of the Fatherland: Turnen and the national Movement (1810-1820).” Sporting Heritage 1, no. 1, (1996), 14-35.

Prohl, Robert. Grundriss der Sportpädagogik 1999. Wiebelsheim: Limpert, 2010.

Schmitt, Hanno. "Die Anfänge des Schulsports im 18. Jahrhundert." In Vernunft und Menschlichkeit: Studien zur philanthropischen Erziehungsbewegung, 209-22. Bad Heilbrunn: Klinkhardt, 2007.

Stolk, Vincent, Willeke Los, and Wiel Veugelers. "Physical Education for Citizenship or Humanity? Freethinkers and Natural Education in the Netherlands in the Mid-Nineteenth Century." In Sport, Health and the Body in the History of Education, ed. Mark Freeman. London, and New York: Routledge, 2015.

Strupler, Ernst. Die Anfänge der modernen Leibesübungen in der Schweiz bis 1833. Winterthur: P. G. Keller, 1955.

Szasz, Thomas. The Medicalization of Everyday Life. Syracuse: University Press, 2007.

Tarcov, Nathan. Locke's Education for Liberty. Chicago: University of Chicago Press, 1984.

Todd, Jan. Physical Culture and the Body Beautiful: Purposive Exercise In the Lives of American Women 1800-1870. Macon: Mercer University Press, 1998.

Toppe, Sabine. Die Erziehung zur guten Mutter: Medizinisch-pädagogische Anleitung zur Mutterschaft im 18. Jahrhundert. Oldenburg: Oldenburg Universität, 1993.

Tröhler, Daniel. Pestalozzi and the Educationalization of the World. New York: Routledge, 2013.

Tröhler, Daniel. "The Medicalization of Current Educational Research and Its Effects on Education Policy and School Reforms." Discourse: Studies in the Cultural Politics of Education 36, no. 5 (2015), 749-64.

Tröhler, Daniel. "Curriculum History, or the Educational Construction of Europe in the Long 19th Century." European Educational Research Journal 15, no. 3 (2016), 279-97.

Tröhler, Daniel, Thomas S. Popkewitz and David F. Labaree, David F. "Introduction - Children, Citizens, and Promised Lands: Comparative History of Political Cultures and Schooling in the Long 19th Century." In Schooling and the Making of Citizens in the Long Nineteenth Century: Comparative Visions, edited by Daniel Tröhler, Thomas S. Popkewitz and David F. Labaree, 1-30. New York: Routledge, 2011. 
Van Strien-Chardonneau, Madeleine. "Holland." In Encyclopedia of the Enlightenment, volume 1, edited by Michel Delon, 656-60. London and New York: Routledge, 2002.

Zajda, Joseph, ed. Nation-Building and History Education in a Global Culture. Dordrecht: Springer, 2015.

Zelle, Carste, ed. "Vernünftige Ärzte:" Hallesche Psychomediziner und die Anfänge der Anthropologie in der deutschsprachigen Frühaufklärung. Tübingen: Max Niemeyer, 2001. 